\title{
Jogo AminoUNO: uma ferramenta alternativa para o ensino da síntese de proteínas no ensino médio
}

\author{
AminoUNO game: an alternative tool for the teaching of protein synthesis \\ in high school
}

\author{
Maria Isabel da Silva ${ }^{1 *}$, Silviane Bezerra Pinheiro ${ }^{1}$, Sthefany Ananda Bruna Almeida Mendes ${ }^{1}$, Thiago Willian \\ Moreira Campelo ${ }^{1}$, Yago Vinícius Serra dos Santos ${ }^{1}$, Maria Cláudia Gross ${ }^{2}$ e Doriane Picanço Rodrigues ${ }^{3}$ \\ *email: mariaisa21silva@gmail.com \\ ${ }^{1}$ Curso de Ciências Biológicas, Instituto de Biologia, Universidade Federal do Amazonas. \\ ${ }^{2}$ Laboratório de Genética Animal, Depto. de Biologia, Instituto de Ciências Biológicas, Universidade Federal \\ do Amazonas. \\ ${ }^{3}$ Laboratório de Evolução Aplicada, Depto. de Biologia, Instituto de Ciências Biológicas, Universidade \\ Federal do Amazonas.
}

\section{Resumo}

A aplicação de jogos lúdicos práticos e criativos como metodologia de ensino tem mostrado grande eficácia na transferência do conhecimento científico para alunos do Ensino Médio em torno de áreas como a Genética, que tem ganhado enorme visibilidade, graças aos meios de comunicação, por exemplo. Visando a contribuir nessa interação teórico-prática nas salas de aulas, o jogo didático AminoUNO foi desenvolvido para ilustrar o processo de síntese de proteínas através da tradução dos nucleotídeos em aminoácidos, bem como a influência da mutação sobre este processo. Somando a isso, o jogo visa a facilitar a compreensão da degeneração do código genético utilizando apenas um baralho confeccionado com cola, tesoura, papel cartão e os modelos impressos das cartas.

Palavras-chave: jogo educativo, tradução do DNA, síntese de proteínas, aminoácidos

\begin{abstract}
The application of educational games as practical and creative teaching methodology has shown great efficacy in transfer scientific knowledge in complex areas such as genetics that everyday becomes evident in the society through the popularization of its information. Aiming to contribute to this interaction between theory and practice in classroom, the educational AminoUNO game was developed to simulate the protein synthesis process as the translating of nucleotide into amino acids, and also the influence of the mutation on this process. In addition, the game aims to facilitate the understanding of the degeneration of the genetic code using only a deck made with glue, scissors, cardboard, and letters models printed on paper.
\end{abstract}

Keywords: educational games, DNA translation, protein synthesis, amino acids 


\section{Ficha da atividade desenvolvida}

Título: Jogo AminoUNO: uma ferramenta alternativa para o ensino da tradução no Ensino Médio

Público alvo: Estudantes do Ensino Médio

Disciplinas relacionadas: Biologia molecular, Genética

Objetivos educacionais: llustrar ludicamente o processo de tradução de nucleotídeos em aminoácidos e as influências da mutação sobre o processo; promover a participação interativa dos estudantes no processo de ensino-aprendizagem.

Justificativa de uso: $O$ jogo AminoUNO apresenta promissoras vantagens na sua utilização em sala por ser uma ferramenta lúdica de fácil confecção e de baixo custo, ao mesmo tempo em que é capaz de promover a interação entre os conceitos científicos expostos em sala de aula e a dinâmica em que funcionam, criando um processo cooperativo de ensino-aprendizagem.

Conteúdos trabalhados: código genético degenerado, tradução, nucleotídeos, aminoácidos, mutação.

Acesso: Apêndice A 


\section{Introdução}

A biologia molecular tem causado impacto no mundo contemporâneo com as novas perspectivas e possibilidades que tem introduzido na ciência moderna. Contudo, embora os temas relacionados a esta área estejam presentes no cotidiano e cada vez mais visíveis à sociedade, principalmente graças às mídias de comunicação, os professores têm dificuldades na transmissão dos conceitos relacionados aos processos moleculares e os alunos frequentemente não compreendem o que está sendo repassado por tratar-se de um assunto abstrato e que não pode ser visualizado a olho nu [1]. Essa situação é agravada pela insuficiência e precariedade infraestrutural das escolas públicas brasileiras, que não dispõe dos refinados modelos didáticos disponíveis no mercado. Diante disso, modelos educativos de fácil preparo e de baixo custo têm ganhado espaço e vêm auxiliando a familiarização dos estudantes com os conceitos teóricos apresentados em sala de aula [2] e, por sua vez, tem entrado como elemento essencial no currículo de formação dos educadores [3].

Um conteúdo considerado de difícil compreensão é a universalidade e degeneração do código genético, sendo que a falta de entendimento destes conceitos implica em dificuldade no entendimento da tradução do RNAm para a síntese proteica [4]. Diversas atividades didáticas e lúdicas vêm sendo propostas com o intuito de elucidar que a universalidade do código genético ocorre porque todos os seres vivos apresentam os mesmos nucleotídeos/ribonucleotídeos como material genético e que em todos o RNA mensageiro (RNAm), originado após a transcrição do DNA em RNA, é formado por sequência de ribonucleotídeos, os quais são lidos de três em três durante o processo de tradução, sendo estas trincas chamadas de códons. Estas trincas são formadas pela combinação de três das quatro bases nitrogenadas existentes no RNA mensageiro (adenina- $A$, uracila- $U$, citosina- $C$, guanina- $G$ ) e estas bases podem estar em qualquer posição da trinca ( 4 bases possíveis na posição $1 \times 4$ bases possíveis na posição $2 \times 4$ bases possíveis na posição 3), o que totaliza 64 códons [5]. Porém, apesar da existência de 64 códons, estes traduzem apenas 20 aminoácidos, e por este motivo o código genético é considerado degenerado, pois um aminoácido é codificado por mais de um códon [6]. Apesar desta redundância, o código genético não é ambíguo, pois o mesmo códon não serve para dois aminoácidos diferentes [7-10]. Porém, nem sempre é fácil compreender estes conceitos e diante da dificuldade que tem sido observada em sala de 
aula, o jogo didático AminoUNO foi desenvolvido para demonstrar de forma simples e lúdica o processo de tradução dos nucleotídeos em aminoácidos, permitindo que os jogadores verifiquem na prática a degeneração do código genético. Além disso, o jogo permite a compreensão de como a mutação pode alterar o processo de tradução, assim como demonstra o processo de finalização promovido pela presença de códons de parada. Assim sendo, este jogo visa a contribuir para um processo dinâmico de ensino e aprendizagem sobre as bases de um processo do dogma central da biologia molecular, tendo como base a tradicional brincadeira de baralho.

\section{Desenvolvimento e aplicação}

\subsection{Confecção do material}

O baralho é formado por 107 cartas divididas da seguinte forma, sendo explicadas as suas funções no quadro 1:

- 64 cartas de bases nitrogenadas (A, T, C, G);

- 20 cartas de aminoácidos (alanina, arginina, asparagina, aspartato, glutamato, cisteína, fenilalanina, glicina, glutamina, histidina, isoleucina, leucina, lisina, metionina, prolina, serina, tirosina, treonina, triptofano, valina).

- 04 cartas mutantes

- 19 cartas de ação, sendo: 4 cartas de "Compre +2"; 2 cartas de "Compre +4"; 8 cartas de "Reverso"; 2 cartas de "Escolha"; 3 cartas de "Parada"

Para a confecção das cartas, serão utilizados os seguintes materiais:

a) Cola branca;

b) Tesoura sem ponta;

c) Papel cartão - 48 x $66 \mathrm{~cm}$, para permitir maior resistência à carta;

d) Papel contacte transparente $-2 \mathrm{~m} \times 45 \mathrm{~cm}$, para permitir uma maior durabilidade ao cartão;

e) Impressão colorida do modelo das cartas (figuras de 1 a 6)

Recorte as cartas-modelo (Apêndice A, figuras 1 a 6) e cole-as no papel cartão. Espere secar e depois finalize encapando com o papel contacte. Observe atentamente a quantidade de cada carta na legenda das figuras antes da impressão. 


\subsection{Modo de jogar}

O objetivo do jogo é fazer com que os participantes entendam que o códon é formado por uma trinca de nucleotídeos e que estes são responsáveis pela codificação de aminoácidos. Além disso, permite que os jogadores percebam que o processo de tradução só inicia com o códon de iniciação e acaba com códons de parada, sendo possível também compreender a degeneração do código genético e a influência de mutações no processo em questão.

\subsubsection{Regras}

1 - Os participantes deverão sentar-se em círculo e as 107 cartas que compõem o baralho serão embaralhadas (as informações referentes às cartas do baralho estão disponíveis no Quadro 1). Cada participante receberá seis cartas viradas com a face contendo a informação voltada para baixo. Os participantes devem segurar as cartas que receberam de maneira que seus oponentes não consigam verificar os seus conteúdos. As demais cartas do baralho devem ser empilhadas no centro do círculo, viradas para baixo, de forma que todos os jogadores tenham acesso a elas quando precisarem.

2 - Para início do jogo, cada participante contará quantas cartas "Aminoácidos" recebeu e informará ao grupo. Aquele que tiver o maior número de cartas "Aminoácidos" será o primeiro jogador e deverá iniciar o jogo liberando uma carta contendo um nucleotídeo " $\mathrm{A}$ " de qualquer cor. $\mathrm{O}$ segundo jogador será o que estiver à esquerda de quem colocou o " $\mathrm{A}$ " na mesa, devendo liberar uma carta "U" da mesma cor que a primeira carta liberada na mesa ("A"). Caso o segundo jogador não tenha esta carta, ele tem o direito de pegar uma única carta da pilha que está no centro da mesa, na tentativa de conseguir encontrar a carta certa a ser utilizada. Se a carta comprada não servir para a jogada, o participante guarda essa carta na mão para descartá-la em outro momento, passando a vez de jogar para o participante que está a sua esquerda. Estes critérios de compra de carta poderão ser utilizados em todas as jogadas, desde que o jogador não disponha de carta que efetue a combinação necessária. Uma vez liberada a segunda carta na mesa ("U" da mesma cor que o primeiro "A"), o jogador que estiver na vez deve obrigatoriamente liberar a carta "G" da mesma cor que o "A" e o "U" que já estão expostos na mesa, para formar a trinca de iniciação da tradução que codifica para metionina. $O$ jogador que possuir esse aminoácido deve descartá-lo na mesa, independentemente se é 
ou não sua vez. Neste momento o professor responsável pela atividade aproveita para ressaltar que a metionina é o primeiro aminoácido adicionado à qualquer cadeia polipeptídica e que é codificado exclusivamente pelo códon AUG, não havendo outro códon para este aminoácido, apesar de o código genético ser degenerado.

3 - O participante que colocou a última base nitrogenada que gerou a trinca correspondente ao aminoácido descartado deve ser "presenteado" com as três cartas base nitrogenada da trinca, ficando com estas três cartas em mãos. Se o jogador que descartou o aminoácido for o mesmo que colocou a última base da trinca, o participante que colocou a segunda base da trinca deve ficar com as três últimas bases que estão sobre a mesa. Esta regra é utilizada no descarte de todos os outros aminoácidos.

4 - Para dar continuidade ao jogo, o jogador que descartou o aminoácido tem o direito de recomeçar. Para tanto, a próxima carta a ser descartada deve ser um nucleotídeo igual ao último da trinca anterior, porém de qualquer cor. Por exemplo, após a trinca AUG o jogador que descartou o aminoácido metionina deverá descartar um "G" de qualquer cor. Depois deste reinício, sempre o jogador que estiver à esquerda deverá se basear na última carta descartada e poderá liberar cartas que sejam da mesma cor (amarela, vermelha, verde, azul) ou da mesma base nitrogenada (A, U, G, C) que a carta jogada anteriormente, sendo este o procedimento a ser adotado durante todo o jogo, após a iniciação com o códon AUG. Isto é, se a última carta que foi posta à mesa for um "A" azul, a próxima carta a ser jogada poderá ser uma carta "A" de qualquer cor ou deve ter a cor azul, podendo apresentar qualquer base nitrogenada (A, U, C ou G). Novamente, as cartas liberadas formarão trincas e quando o códon exposto corresponder a um aminoácido, o jogador que possuir esse aminoácido deve descartá-lo, independentemente se é ou não sua vez. Caso nenhum jogador tenha o aminoácido correspondente à trinca formada, um novo nucleotídeo deverá ser adicionado para compor a nova trinca, sendo retirada do jogo a primeira base, até que um jogador tenha na sua vez de jogar um aminoácido correspondente à trinca. Neste momento o professor poderá explicar que 0 RNAm pode ser formado regiões codificantes (éxons) e não codificantes (íntrons), sendo as últimas removidas do RNAm final. Além disso, durante o descarte dos aminoácidos, o professor deve enfatizar os diferentes códons que podem codificar um mesmo aminoácido, ressaltando que isso implica na degeneração do códon genético, ou seja, vários códons para um mesmo aminoácido. Além disso, deve deixar claro que apesar de 
degenerado, o código genético não é ambíguo, pois o mesmo códon não serve para dois aminoácidos diferentes.

5 - Para continuação do jogo, sempre voltar ao passo 4 , obedecendo às regras de compra e descarte.

6 - Além disso, cartas adicionais aparecerão durante o jogo. Por exemplo, o participante que tiver em sua mão a carta "Mutante" poderá jogá-la durante a sua vez, sem precisar obedecer à cor ou à letra da carta anterior, dando ao jogador a possibilidade de jogar mais uma carta, para iniciar uma nova trinca. Neste momento, o professor aproveita para explicar que mutações podem ocorrer e que elas não obedecem à regras, podendo modificar sequências do DNA/RNA e consequentemente podendo alterar a cadeia de aminoácidos.

7 - A carta "parada" representa os códons de parada existentes no processo de tradução e se alguma das três trincas de parada aparecer no decorrer do jogo, o participante que tiver a carta "parada" correspondente deve liberá-la na mesa e assim ganhará o jogo, pois acabará o processo de tradução. Neste caso, o professor deverá explicar que sempre que tiver um código de parada no RNAm, a tradução será finalizada, independente se a molécula de RNA ainda tiver bases subsequentes.

8- As outras cartas do baralho ("Reverso, Escolha, Compre +2, Compre +4") apenas têm o objetivo de tornar o jogo mais dinâmico. A carta "Reverso" pode ser jogada durante a vez do jogador que a possuir, se ela corresponder a mesma cor da última carta "base nitrogenada" jogada. Esta carta ocasiona a mudança do sentido do jogo, isto é, do sentido horário para o anti-horário, e vice-versa. A carta "Escolha" (roxa) pode ser liberada independente da cor ou letra da carta anterior e dá ao jogador o poder de escolher a cor das próximas cartas a serem jogadas, podendo ser usada apenas na vez do jogador que a possuir. A carta "Compre +2" pode ser liberada durante a vez de quem a possui, respeitando a cor da carta anterior e faz com que o próximo jogador receba duas novas cartas do baralho. A carta "Compre +4 " pode ser liberada na vez de quem a possui, independente da cor da base nitrogenada anterior, dando ao jogador o poder de escolher a cor das próximas cartas, além de fazer com que o próximo jogador compre quatro cartas do baralho.

9 - Durante todo o jogo, quando o jogador tiver apenas uma carta na mão ele precisa falar "TRADUÇÃO", caso contrário será punido com a obrigatoriedade da compra 
de três novas cartas. Vence o jogador que descartar todas as suas cartas ou quem tiver o menor número de cartas quando a carta "parada" for jogada por um dos participantes, o que indica o fim do jogo.

Quadro 1. Cartas e suas funções dentro do jogo.

\begin{tabular}{|c|c|}
\hline Carta & Descrição \\
\hline Compre +2 & $\begin{array}{l}\text { O participante que tiver em mãos a carta "Compre +2" pode liberá-la na sua vez, } \\
\text { respeitando a cor da última carta "base nitrogenada" que foi jogada. O próximo } \\
\text { jogador deve pegar } 2 \text { (duas) duas novas cartas. }\end{array}$ \\
\hline Compre +4 & $\begin{array}{l}\text { O participante que tiver em mãos a carta "Compre }+4 \text { " pode liberá-la na sua vez, } \\
\text { independente da última carta "base nitrogenada" que foi jogada, dando ao jogador o } \\
\text { poder de escolher a cor das próximas cartas e obrigando o próximo jogador a pegar } 4 \\
\text { (quatro) novas cartas do baralho. }\end{array}$ \\
\hline Reverso & $\begin{array}{l}\text { A ordem do jogo é invertida, do sentido horário para o sentido anti-horário, e vice- } \\
\text { versa. Se o jogo for jogado por duas pessoas, a carta é tratada com o mesmo sentido } \\
\text { de pular, ou seja, o jogador perde a vez na jogada. }\end{array}$ \\
\hline Mutante & $\begin{array}{l}\text { A carta "Mutante" pode ser jogada apenas na vez por quem a possui, sem precisar } \\
\text { obedecer à cor ou à letra da carta anterior, dando ao jogador a possibilidade de } \\
\text { liberar outra carta e iniciar uma nova trinca. }\end{array}$ \\
\hline Escolha & $\begin{array}{l}\text { O jogador escolhe qual deve ser a cor para que o jogo prossiga. Esta carta só deve } \\
\text { ser jogada na vez de quem a possui. }\end{array}$ \\
\hline $\begin{array}{l}\text { Parada } \\
\text { "UAG" } \\
\text { "UGA" } \\
\text { "UAA" }\end{array}$ & $\begin{array}{l}\text { A carta "parada" representa os códons de parada existentes no processo de tradução } \\
\text { e, se alguma das três trincas de parada for formada no decorrer do jogo, o } \\
\text { participante que tiver a carta "parada" correspondente deve liberá-la na mesa. Após } \\
\text { isso, o jogo é vencido pelo participante que estiver com o menor número de cartas. }\end{array}$ \\
\hline $\begin{array}{l}\text { Bases } \\
\text { nitrogenadas } \\
(A, U, G, C)\end{array}$ & $\begin{array}{l}\text { O jogador da vez deve colocar uma carta que contenha a mesma cor ou a mesma } \\
\text { base nitrogenada }(A, G, U, C) \text { contida na carta anterior que já está na mesa, até } \\
\text { formar uma trinca. }\end{array}$ \\
\hline Aminoácidos & $\begin{array}{l}\text { Na altura em que uma trinca de bases nitrogenadas for formada no jogo, a carta } \\
\text { "aminoácido", que corresponde ao aminoácido codificado pela trinca, pode ser } \\
\text { descartada por qualquer um dos jogadores. }\end{array}$ \\
\hline
\end{tabular}


Após o jogo, o professor poderá efetuar um questionário para avaliar a compreensão dos alunos sobre o tema. Dentre as questões a serem abordadas, sugerem-se:

- Qual a relação da forma como o jogo se inicia com o início da tradução?

- Por que as cartas são organizadas de três em três durante o jogo? O que isso representa?

- Qual o papel da carta "Mutante" e o que ela representa durante o processo de tradução?

- No jogo pode-se ganhar de duas formas: tendo o menor número de cartas quando a carta "parada" for liberada por um dos participantes, ou ficando sem nenhuma carta na mão. Relacione a carta "parada" com o processo de tradução.

\section{Reflexão}

O jogo AminoUNO foi desenvolvido para ser uma alternativa barata e eficiente na transmissão dos conhecimentos científicos de forma fácil e interativa. O jogo pôde ser aplicado a estudantes do Ensino Médio da rede pública de Manaus, durante a $2^{\mathrm{a}}$ Oficina "O que isso tem a ver com a Genética?", na Universidade Federal do Amazonas. Desde o primeiro momento, os estudantes demonstraram grande interesse em participar da atividade. Ao passo em que o jogo acontecia, dúvidas a respeito das regras surgiram e neste momento foi possível instigar os estudantes a correlacionarem a lógica do jogo com a dinâmica dos processos biológicos envolvidos.

Tabela 1. Resultado da pesquisa avaliativa sobre a impressão causada pelo jogo nos participantes $(n=15)$.

\begin{tabular}{llcc}
\hline Perguntas & Respostas & $\mathbf{N}^{\circ}$ de votos & $\%\left(^{*}\right)$ \\
\hline & Educativo & 13 & 86,66 \\
& Interessante & 7 & 46,66 \\
O que você achou do jogo? $\left(^{*}\right)$ & Divertido & 5 & 26,66 \\
& Interativo & 4 & 33,33 \\
& Fácil de jogar & 1 & 6,66 \\
\hline O jogo pode ser aplicado em sala de aula para o o & Sim & 15 & 100 \\
ensino de Genética? & Não & 0 & 0 \\
\hline & Ruim & 0 & 0 \\
Avaliando a proposta do jogo AminoUnO, qual o o & Regular & 1 & 6,66 \\
\cline { 2 - 4 } seu nível de satisfação? & Bom & 1 & 6,66 \\
\cline { 2 - 4 } & Ótimo & 13 & 86,66 \\
\hline
\end{tabular}

*votos contabilizados com base no número de questionários em que cada uma dessas respostas foi utilizada pelos participantes. 
Ao final, em uma conversa reflexiva, foi introduzido o questionário mencionado anteriormente, seguido por uma pesquisa avaliativa do interesse e satisfação dos alunos em usarem o jogo em suas escolas (Tabela 2). As respostas dos estudantes apresentaram uma boa assimilação dos conceitos ensinados durante a atividade, bem como um alto nível de satisfação e de aplicabilidade do jogo como ferramenta de ensino nas respostas discursivas:

- "Achei muito interessante porque incentiva o aprendizado da Genética de uma forma divertida." - Depoimento de um estudante do $1^{\circ}$ ano do Ensino Médio.

- "O jogo é uma forma de aprender brincando." - Depoimento de uma estudante do $2^{\circ}$ ano do Ensino Médio.

- "O jogo é bastante educativo e fácil de jogar. É um modo mais fácil de aprender Genética." - Depoimento de um estudante do $3^{\circ}$ ano do Ensino Médio.

Dessa forma, ficou evidente o potencial do jogo AminoUNO como mais uma atividade lúdica ao alcance de educadores e estudantes para colaborar no processo de ensino-aprendizagem. Sem dúvida, há ainda espaço para que os educadores possam ajustar a arquitetura do jogo de maneira a explorar ao máximo o seu potencial.

\section{Referências}

[1] Temp DS. Facilitando a aprendizagem de Genética: uso de um modelo didático e análise dos recursos presentes em livros de Biologia. [Dissertação de mestrado]. Universidade Federal de Santa Maria, Rio Grande do Sul; 2011.

[2] Scheid NMJ, Ferrari N. A história da ciência como aliada no ensino da genética. Genética na Escola. 2006; 1(1): p. 17-18.

[3] Setúval FAR, Bejarano NRR. Modelos didáticos com conteúdos de Genética e a sua importância na formação inicial de professores para o ensino de Ciências e Biologia. In Encontro Nacional de Pesquisa em Educação em Ciências; 2009.

[4] Camargo SS, Infante-Malachias ME. A genética humana no Ensino Médio: algumas propostas. Genética na Escola. 2007; 2(1): p. 14-16.

[5] Alberts B, Bray D, Hopkin K. Fundamentos de Biologia Celular. 2 ed. São Paulo: Artmed; 2006.

[6] Griffiths AJF, Lewontin RC, Carroll SB, Wessler SR. Introdução à Genética. Rio de Janeiro: Guanabara Koogan; 2009.

[7] Mori L, Arias MC, Miyaki CY, Dessen EMB. Código genético: o código dos vinte. Genética na Escola. 2009; 04(1): p. 25-32. 
[8] Siqueira SS, Borges, JS; Carvalho G et al. Brincando com as trincas: para entender a síntese protéica. Genética na Escola. 2010; 5(1): p. 34-37.

[9] Magalhães PFX; Silva MCR, Araújo NH, Moreira PA. Construindo os ácidos nucléicos. Genética na Escola. 2011; 6(1): p. 16-23.

[10] Castilho-Fernandes A, Pessolato AGT, Souza LEB, Bonfim-Silva R, Ferreira PCG, Daré GLR. Utilização do jogo "salada de aminoácidos" para o entendimento do código genético degenerado. Genética na Escola. 2011; 6(2): p. 60-67.

\section{Agradecimentos}

À Jéssica Tavares, Magda Silva e Sara Maia pela ajuda na confecção do jogo e pelas sugestões dadas. À CAPES pelo financiamento do projeto Difundindo e Popularizando a Ciência a partir da interação-reflexão-ação entre a Universidade e a Educação Básica - UFAM, integrante da Rede Jovens Talentos da Rede Pública. 
Apêndice A. Cartas do jogo para impressão.
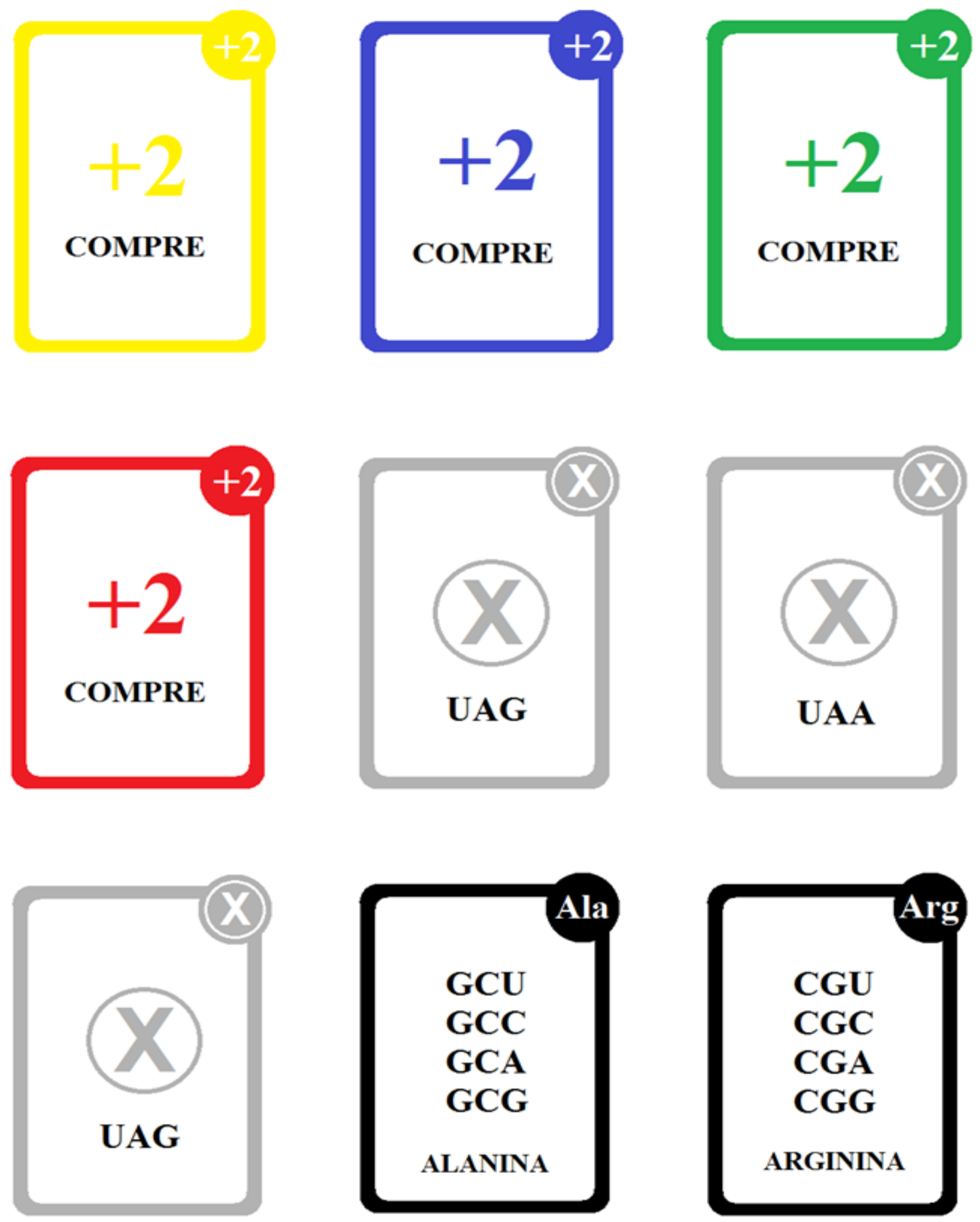

Figura 1 - Modelo das cartas: "Compre +2", "Parada" e "Aminoácido". Cada carta dessa figura contém 1 (uma) unidade no jogo, portanto, é necessário imprimir esta página apenas uma única vez. 

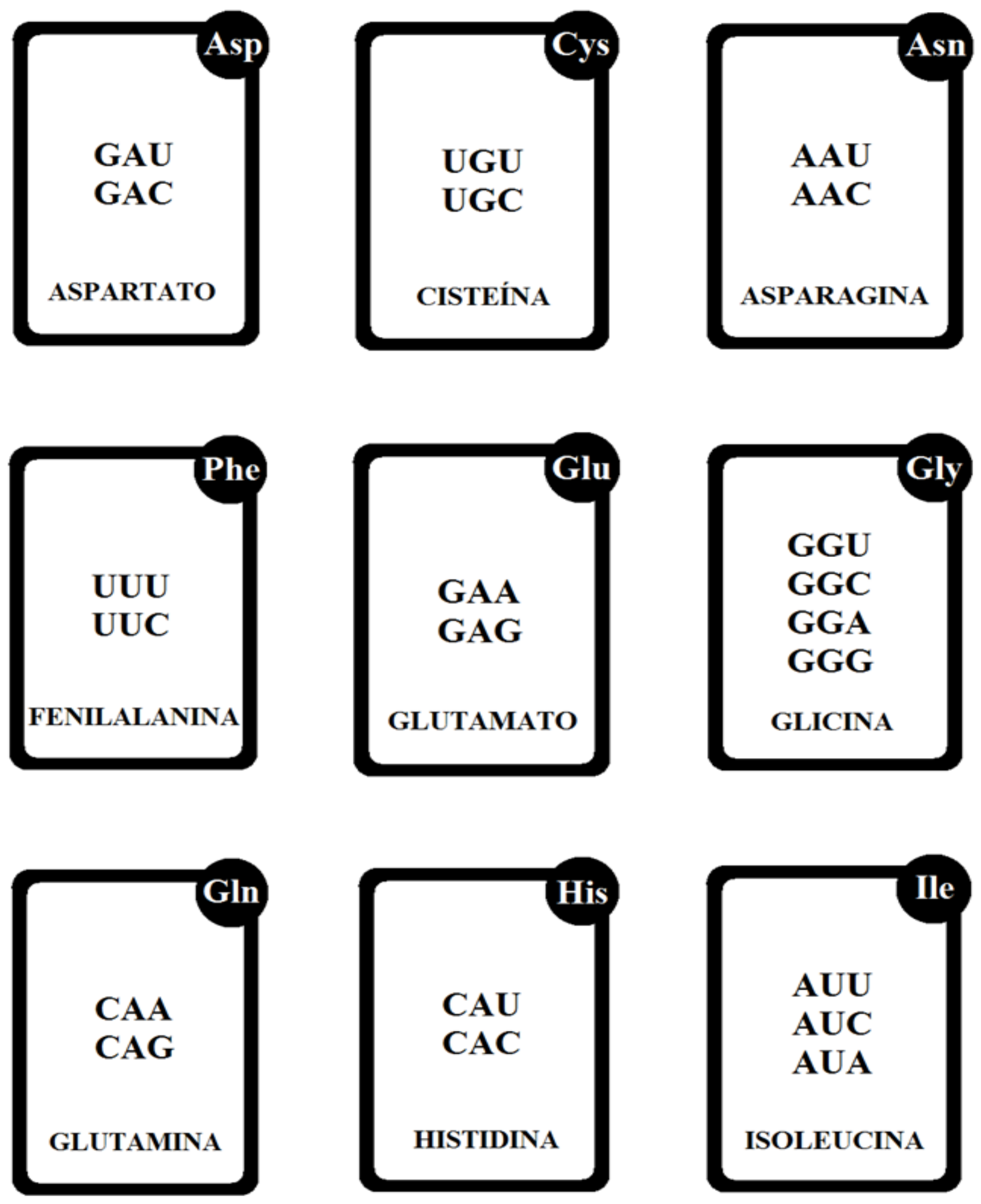

Figura 2 - Modelo de carta: "aminoácido". Cada carta dessa figura contém 1 (uma) unidade no jogo, portanto, é necessário imprimir esta página apenas uma única vez. 

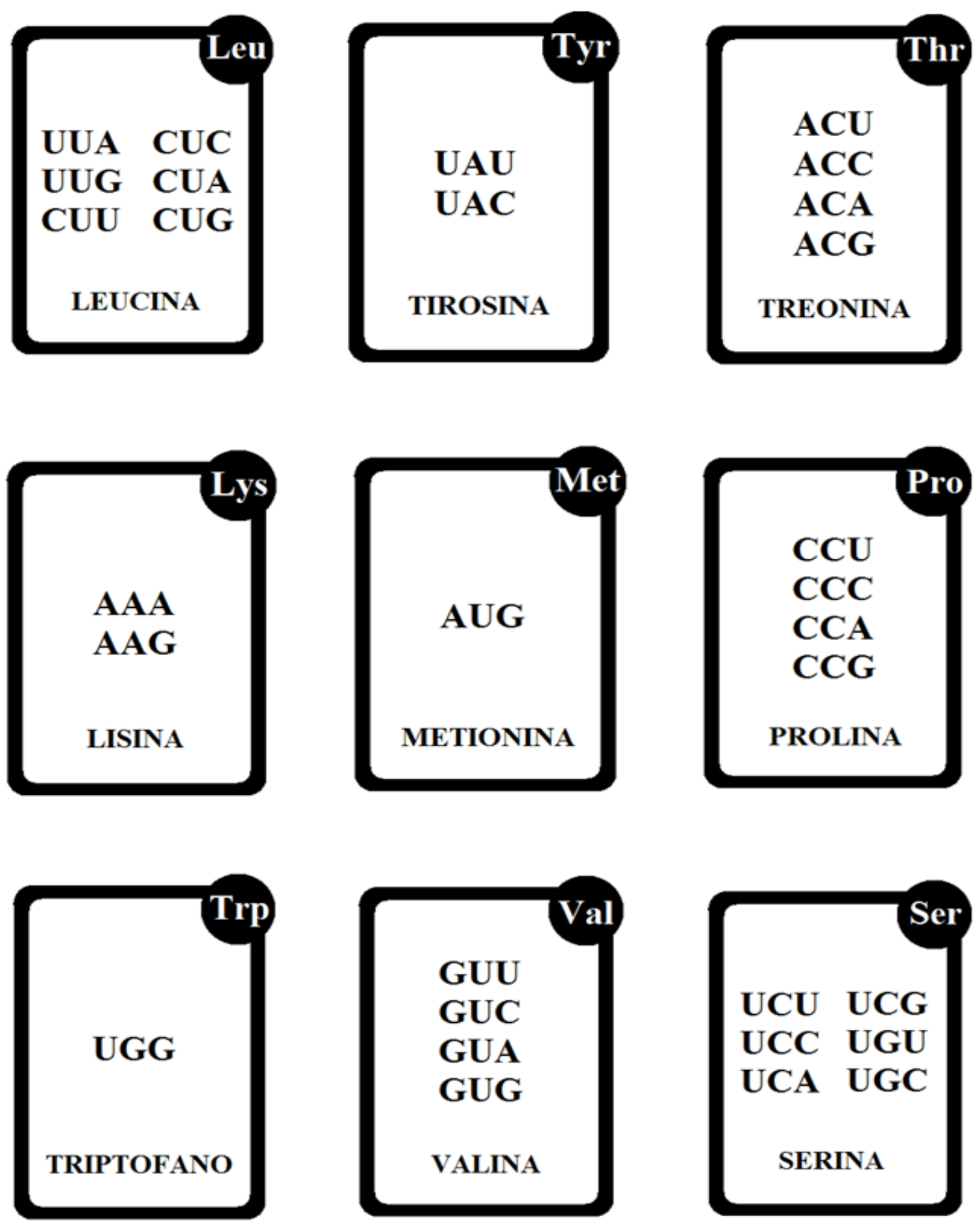

Figura 3 - Modelo de carta-aminoácido. As cartas dessa figura contém 1 (uma) unidade no jogo, portanto, é necessário imprimir esta página apenas uma única vez. 


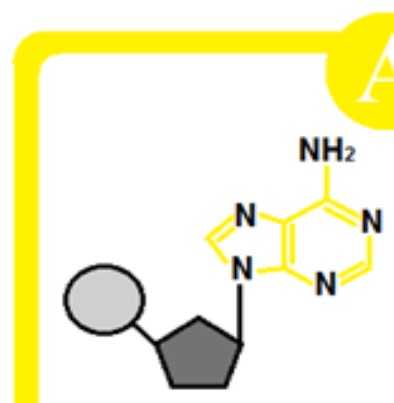

ADENINA
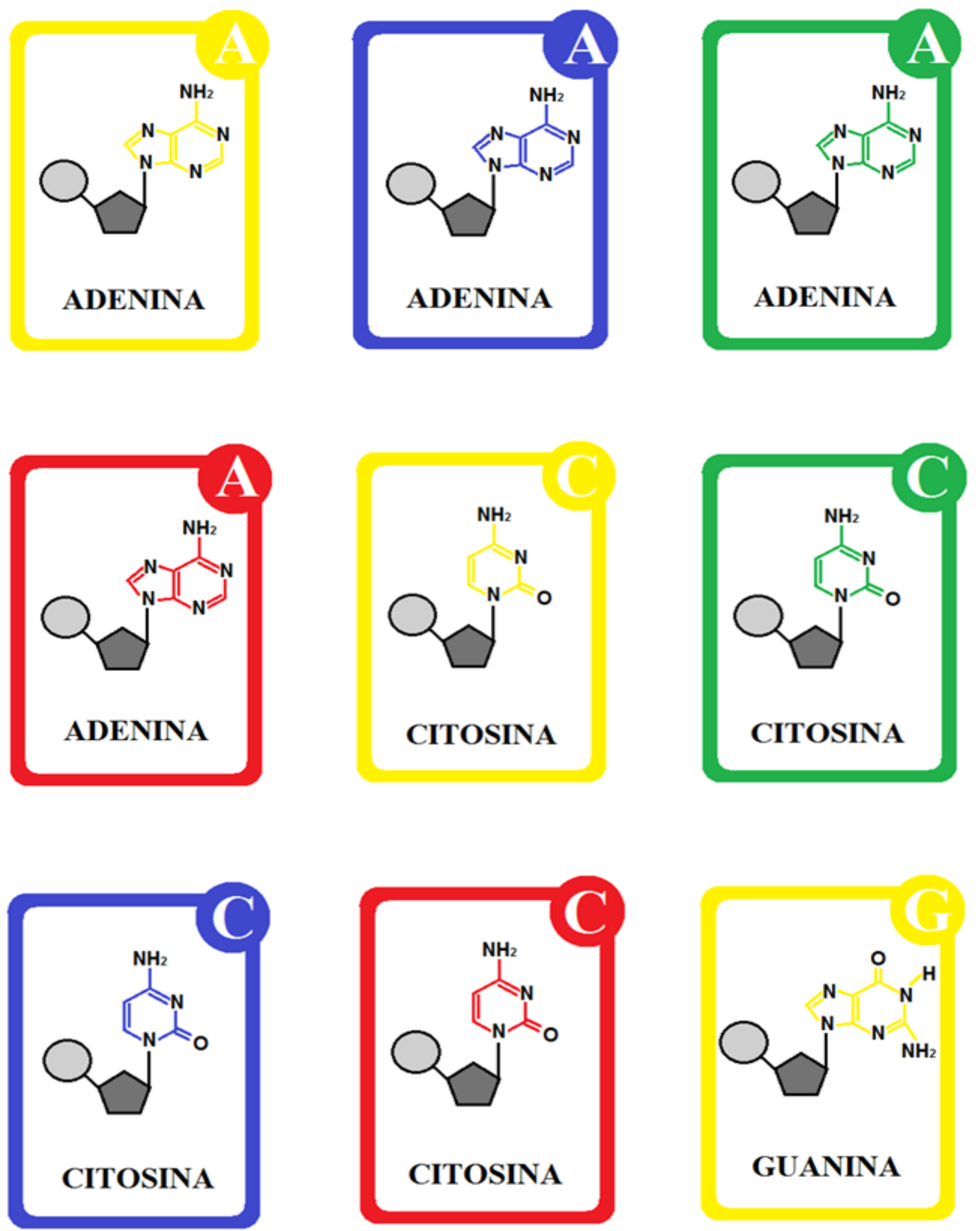

Figura 4 - Modelo de carta-nucleotídeo. Cada carta dessa figura contém 4 (quatro) unidades no jogo, portanto, é necessário imprimir esta página quatro vezes. 

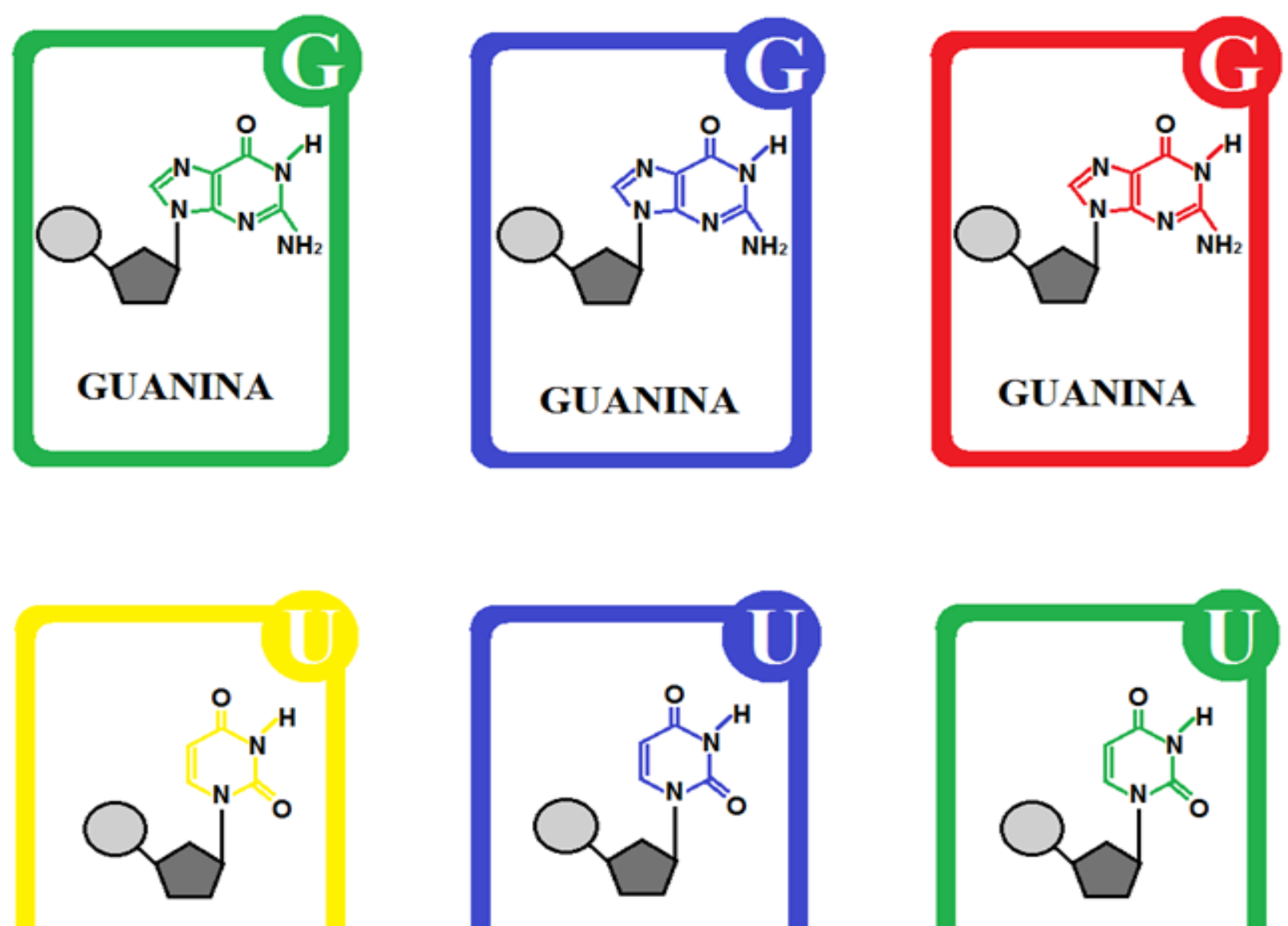

URACIL
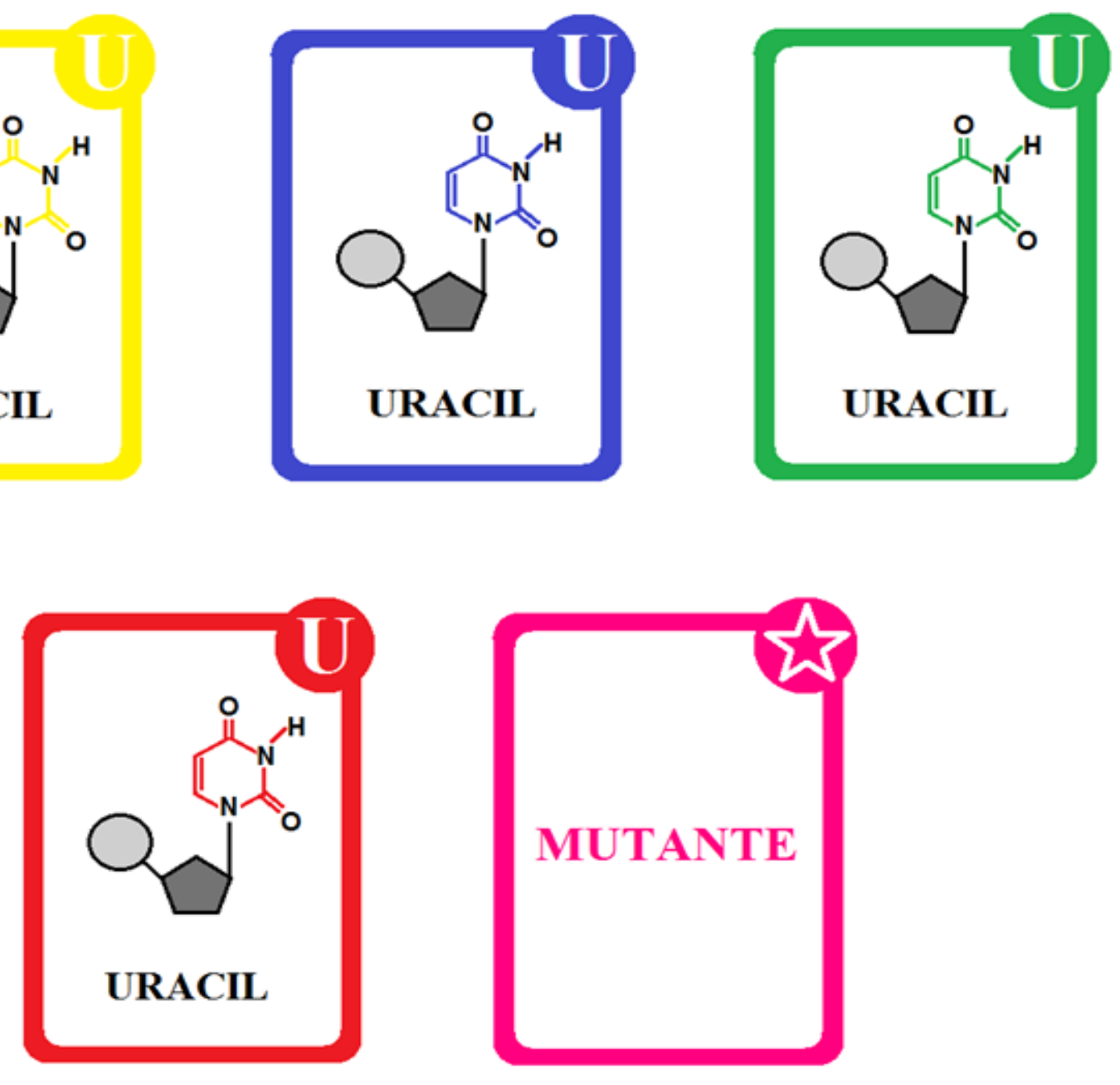

Figura 5 - Modelo de carta-nucleotídeo e carta-mutante. Cada carta desta figura contém 4 (quatro) unidades no jogo, portanto, é necessário imprimir esta página quatro vezes. 

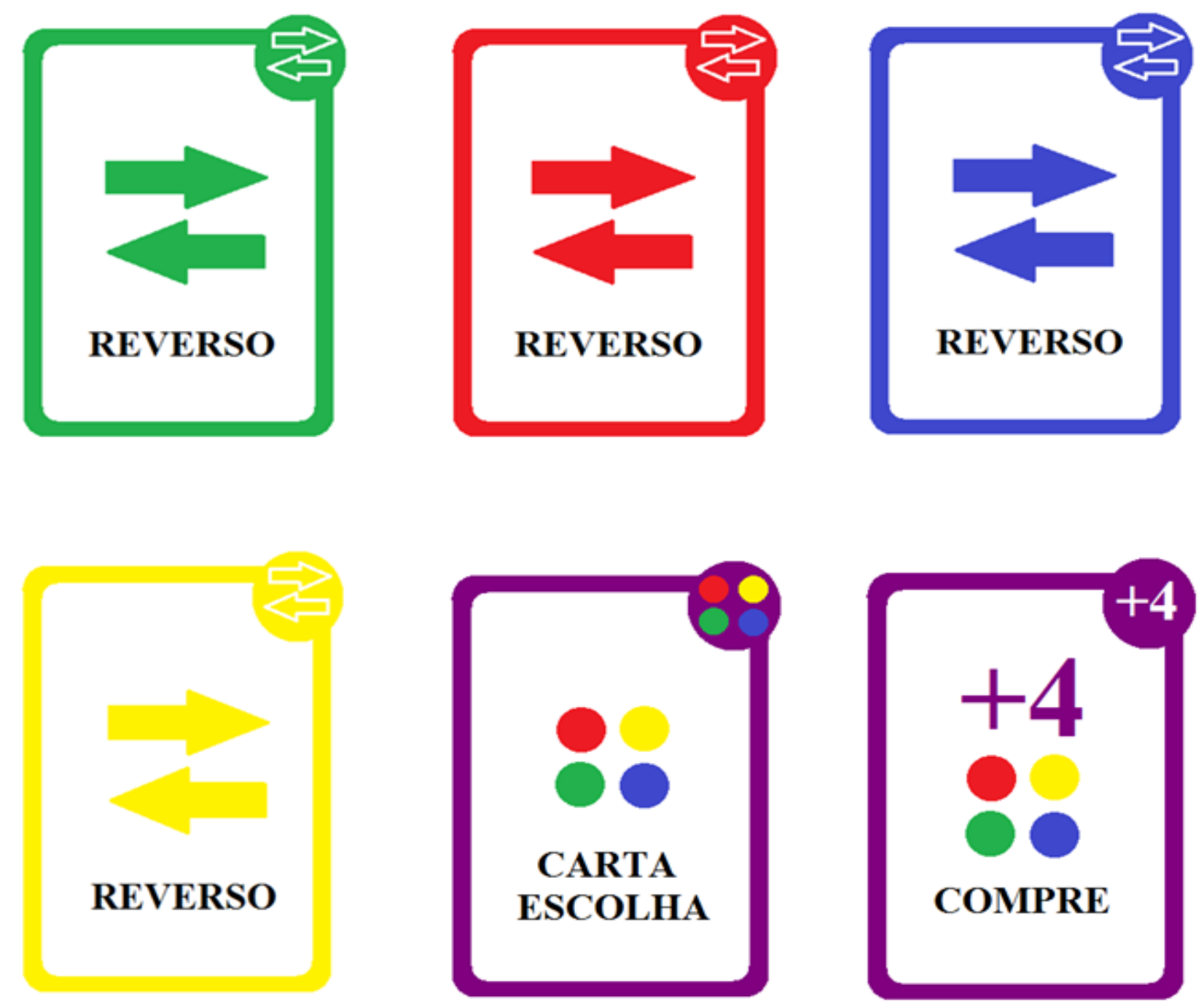

Figura 6. Modelo de carta-reverso, carta-escolha e carta "compre +4 ". Cada carta dessa figura contém 2 (duas) unidades no jogo, portanto, é necessário imprimir esta página duas vezes. 